\title{
RIBONUCLEIC ACID SYNTHESIS IN Streptomyces \\ antibioticus: STABLE RIBONUCLEIC \\ ACID SPECIES SYNTHESIZED BY YOUNG \\ AND OLD CELLS
}

\author{
George $H$. Jones \\ Department of Zoology \\ University of Michigan \\ Ann Arbor, Michigan 48104
}

Received December 9,1974

SUMMARY: In studies of RNA synthesis by intact cells and cell-free extracts of Streptomyces antibioticus, it has been found that $48 \mathrm{hr}$ cells (producing actinomycin) and cel1-free extracts are less efficient than $12 \mathrm{hr}$ cells (not producing actinomycin) and extracts in the synthesis of RNA. Analysis of the products of "in vivo" and "in vitro" RNA synthesis by sucrose gradient centrifugation reveals that both 12 and $48 \mathrm{hr}$ cultures and cell-free extracts synthesize ribosomal RNA as well as RNA species of higher and lower mole-

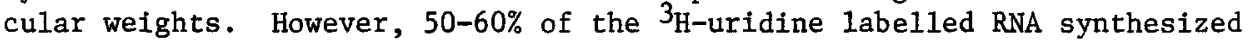
by intact cells sediments as rRNA as compared with only $5-10 \%$ of the cellfree product. The addition of $2 \times 10^{-5} \mathrm{M}$ actinomycin $\mathrm{D}$ to incubation mixtures for cell-free RNA synthesis does not significantly alter the relative amounts of the various RNA species synthesized by 12 or $48 \mathrm{hr}$ extracts.

Streptomyces antibioticus is one member of the genus which produces the antibiotic, actinomycin (1). In previous studies, it has been shown that a decrease in the capacity for macromolecular synthesis accompanies the production of actinomycin by $\underline{s}$. antibioticus (2-4). In particular, RNA and protein synthesis decline dramatically as the cells begin to synthesize antibiotic. Nevertheless, low levels of protein and RNA synthesis are maintained long after the cells have reached stationary phase, despite the fact that most of the cellular energy is utilized in secondary metabolite production during this period $(3,4)$.

It was somewhat surprising to observe continued RNA synthesis in an organism which produces an inhibitor of DNA-dependent RNA synthesis as a secondary metabolite. To examine the molecular basis for the persistence of RNA synthesis in $\underline{s}$. antibioticus cells, certain characteristics of RNA synthesis in intact cells and cell-free extracts has been examined, and the results of these studies are presented below.

\section{MATERIALS AND METHODS}

S. antibioticus, strain 3720, was grown in NZ-amine medium as previously described (5). After $48 \mathrm{hr}$ in this medium, the cells were transferred to galactose glutamic acid medium containing $0.1 \%$ glucose (5). It is in the lat- 
ter medium that the cells produce actinomycin. For the "in vivo" studies, $200 \mathrm{~m} 1$ cultures, grown for 11 or $47 \mathrm{hr}$ in galactose-glutamic acid-glucose medium were labelled for $1 \mathrm{hr}$ with $50 \mu \mathrm{Ci}$ of ${ }^{3} \mathrm{H}$-uridine $(49 \mathrm{Ci} / \mathrm{mmo1})$. At the end of the labelling period, the cells were harvested by suction filtration, washed and sonicated with an MSE ultrasonic power unit at a setting of 1.4 amperes, after suspension in three volumes of $0.1 \mathrm{M}$ Na acetate, 0.1 M NaC1, pH 5.0. Sonicates were centrifuged for $10 \mathrm{~min}$ at $20,000 \mathrm{~g}$. Total RNA was extracted from the 20,000 g supernatants as previous1y described (3). and was analyzed by sucrose gradient centrifugation. Aliquots of the sonicates were precipitated with trichloroacetic acid and the precipitates were collected on glass fibre filters and counted. Results are expressed as cpm incorporated per $\mathrm{mg}$ protein in the sonic extract.

Procedures for the preparation of cell-free extracts will be described in detail in a subsequent publication (in preparation). Briefly, sonic extracts of 12 and $48 \mathrm{hr}$ cultures were filtered through Sephadex G25 and were used without further purification as sources of RNA polymerizing activity. ${ }^{3} \mathrm{H}$-UTP incorporation in these extracts proceded without exogenous DNA and was sensitive to both DNase and RNase. Ce11-free incubations were performed in volumes of $1 \mathrm{ml}$ using ${ }^{3} \mathrm{H}$-UTP as a precursor. Incubation mixtures contained: Tris-HCl, $\mathrm{pH} \mathrm{7.8,} 40 \mu$ moles; $\mathrm{MgCl}_{2}$, 10 moles; potassium EDTA, 0.1 umole; potassium phosphate, pH 7.5, 0.5 umole; bovine serum albumin, $0.5 \mathrm{mg}$; unlabelled ATP, GTP and CTP, 0.15 umole each; ${ }^{3} \mathrm{H}-\mathrm{UTP}$, (19.8 Ci/mo1), 1.25 nmole; dithiothreitol, $0.1 \mu$ mole; and crude extract (12 or $48 \mathrm{hr}$ ), about $2.5 \mathrm{mg}$ protein. Tncubations were carried out for 30 min at $37^{\circ}$ using endogenous DNA as template. Actinomycin D, at a concentration of $2 \times 10^{-5} \mathrm{M}$ was present in some incubations. This concentration of actinomycin is that found in the medium of $48 \mathrm{hr} \underline{\mathrm{S}}$. antibioticus cultures under the growth conditions employed (unpublished observation). RNA was extracted from reaction mixtures as previously described (3). Protein was determined by the method of Lowry, et al. (6).

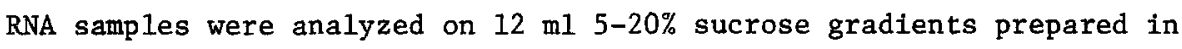
$0.1 \mathrm{M} \mathrm{Na}$ acetate, 0.1 M NaCl, $\mathrm{pH}$ 5.0. Gradients were centrifuged in an SB-283 rotor of the IEC B-60 ultracentrifuge, for the times indicated in the legends to Figs. 1 and 2. At the end of the centrifugations, the gradient tubes were punctured and fractions of 10 drops were collected from the bottom of each gradient. Each fraction was diluted with $0.5 \mathrm{ml} \mathrm{H}_{2} 0$ and its absorbance determined at $260 \mathrm{~nm}$. Thereafter, $0.5 \mathrm{mg}$ of total yeast RNA and $0.5 \mathrm{ml}$ of $50 \%$ trichloroacetic acid were added to each fraction. After standing $10 \mathrm{~min}$ at $0^{\circ}$, the precipitated RNA was collected on glass fibre filters. The RNA samples were dissolved in $1 \mathrm{ml}$ of $95 \%$ Protosol prior to liquid scintillation counting. 
Tncorporation of labelled RNA precursors "in vivo" and "in vitro" - Intact S. antibioticus cells and cell-free extracts of these cells have been used to synthesize RNA, using ${ }^{3} \mathrm{H}$-uridine and ${ }^{3} \mathrm{H}$-UTP respectively, as RNA precursors. For these studies, cells were harvested from cultures before ( $12 \mathrm{hr}$ after innoculation) and after (48 hr after innoculation) the onset of actinomycin synthesis. In experiments in which net RNA synthesis was measured, it was found that $12 \mathrm{hr}$ and $48 \mathrm{hr}$ cells incorporated ${ }^{3}$ H-uridine into RNA at levels of 86,715 and $18,431 \mathrm{cpm} / \mathrm{mg}$ protein respectively. Similarly, 12 $\mathrm{hr}$ and $48 \mathrm{hr}$ cell-free extracts incorporated ${ }^{3} \mathrm{H}$-UMP into RNA at levels of 24,870 and $9,433 \mathrm{cpm} / \mathrm{mg}$ extract protein, respectively. These results verify the decreased ability of actinomycin producing cells to synthesize RNA as compared with younger cells which have not yet commenced antibiotic synthesis. An interesting, but unexpected finding, was the observation that actinomycin inhibited ${ }^{3} \mathrm{H}$-UMP incorporation in $12 \mathrm{hr}$ extracts to a much greater extent than in $48 \mathrm{hr}$ extracts. Thus, in the presence of $2 \times 10^{-5}$ $M$ actinomycin $D$, the levels of ${ }^{3} \mathrm{H}-\mathrm{UMP}$ incorporation by 12 and $48 \mathrm{hr}$ extracts were decreased by $71 \%$ and $3 \%$, respectively, as compared with the levels of incorporation in the absence of the antibiotic. The basis for this difference in actinomycin sensitivity will be reported in a subsequent publication (in preparation).

Sucrose gradient analysis of RNA synthesized "in vivo" and "in vitro" by S. antibioticus - The decreased ability of $48 \mathrm{hr}$ cells to synthesize RNA as compared with $12 \mathrm{hr}$ cells could be explained if the synthesis of certain RNA species (unessential to the $48 \mathrm{hr}$ cell) was preferentially inhibited. Then, the observed cell-free synthesis of RNA by $48 \mathrm{hr}$ extracts might represent the formation of only those species whose synthesis persists in the intact cell. Alternatively, a decrease in cellular capacity for synthesis (or an increased rate of degradation) of all types of RNA might accompany actinomycin production in S. antibioticus. In order to examine these possibilities, and to determine the nature of the RNA's synthesized by S. antibioticus cell-free extracts, the labelled RNA from 12 and $48 \mathrm{hr}$ cells and extracts has been analyzed.

The RNA extracted from sonicates of ${ }^{3}$ H-uridine labelled 12 and $48 \mathrm{hr}$ cultures was analyzed by sucrose gradient centrifugation with the results shown in Fig. 1. The data clearly indicate that both 12 and $48 \mathrm{hr}$ cells contain $16 \mathrm{~s}$ and $23 \mathrm{~s}$ ribosomal RNA's, and that $48 \mathrm{hr}$ cells do incorporate labelled uridine into ribosomal RNA, despite their reduced capacity for protein (4) and RNA synthesis (see preceding section). Fig. 1 also shows 


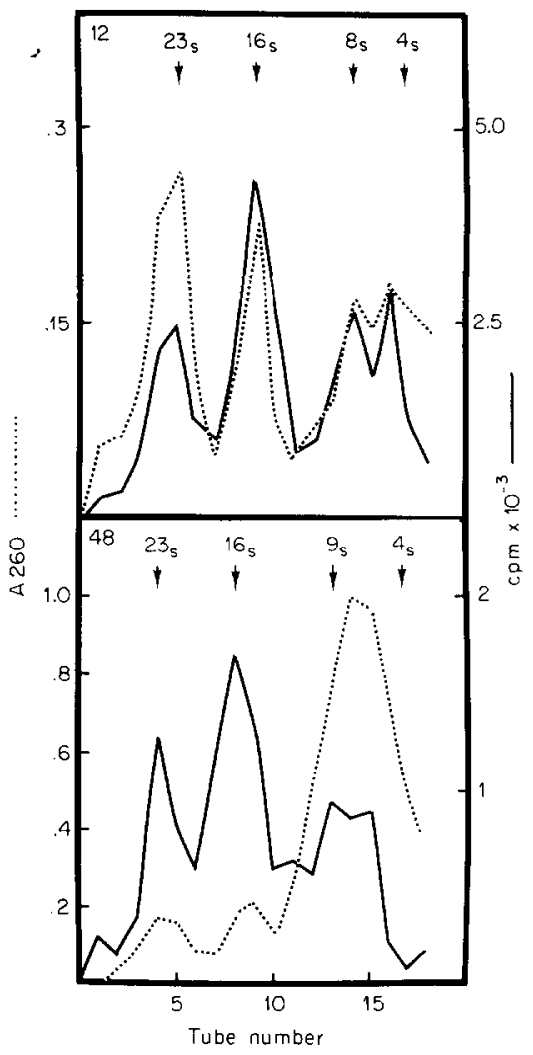

Fig. 1 - RNA's extractd from sonicates of $3_{\text {H-uridine labelled } 12 \mathrm{hr}}$ (top panel) and $48 \mathrm{hr}$ (bottom pane1) cultures of $\underline{\mathrm{S}}$. antibioticus were analyzed by sucrose gradient centrifugation. See Materials and Methods for details of the analysis. Gradients were centrifuged for $13 \mathrm{hr}$ at 36,000 rpm and 10 drop fractions were collected from the bottom of each gradient and processed as described in Materials and Methods. The positions of 16s and 23 s rRNA's were determined using marker RNA's prepared from E. coli cells and run on parallel gradients. The direction of sedimentation is from right to left.

that both 12 and 48 hr cells contain material sedimenting more slowly than $16 \mathrm{~s}$ and more rapidly than 23s. RNA species synthesized by 12 and 48 hr cell-free extracts are displayed in the gradient profiles of Fig. 2 . It can be seen that both 12 and $48 \mathrm{hr}$ extracts support the synthesis of rRNA's and RNA species of higher and lower molecular weights. Similar patterns were obtained when the RNA species synthesized in the presence of actinomycin $D$ were analyzed (data not shown).

The data of Table I give some information on the relative proportions of the various labelled RNA species synthesized by 12 and $48 \mathrm{hr}$ cells and their extracts. It can be seen that there is no great difference in 


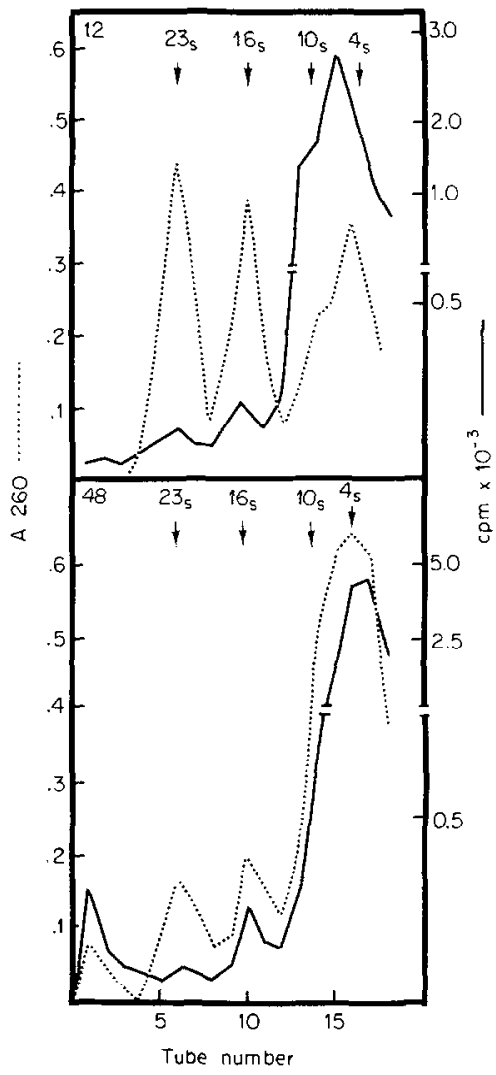

Fig. 2 - Sucrose gradients containing RNA's synthesized by $12 \mathrm{hr}$ (top pane1) and $48 \mathrm{hr}$ (bottom pane1) cell-free extracts were centrifuged for $12 \mathrm{hr}$ at 36,000 rpm and processed as described in Materials and Methods.

the relative amounts of the various RNA species synthesized by the two cultures during the $1 \mathrm{hr}$ labelling period (Table I), despite the fact that net incorporation of ${ }^{3} \mathrm{H}$-uridine by $48 \mathrm{hr}$ cells is significantly reduced relative to the $12 \mathrm{hr}$ culture (see preceding section). Labelled RNA from both cultures contains about 20\% 23s RNA, 35-40\% 16s RNA, 35-40\% RNA sedimenting more slowly than $16 \mathrm{~s}$ and $2-3 \%$ RNA sedimenting faster than $23 \mathrm{~s}$. Further, the data of Table I show that the relative amounts of stable RNA species synthesized by cell-free extracts are not identical to those observed under "in vivo" labelling conditions. A smaller proportion of the labelled RNA synthesized by cell-free extracts is ribosomal ( $5-10 \%$ ) and more $\mathrm{rRNA}$ is synthesized by $12 \mathrm{hr}$ extracts (11\%) than by $48 \mathrm{hr}$ extracts $(6 \%)$. Eighty-five to ninety per cent of the RNA synthesized by cell-free extracts sediments at less than $16 \mathrm{~s}$ as compared with $35-40 \%$ of the RNA labelled "in vivo." A slight increase in the pro- 


\section{TABLE I}

Relative proportions of ${ }^{3} \mathrm{H}$-1abelled RNA observed on sucrose gradient analysis of 12 and $48 \mathrm{hr}$. antibioticus total RNA

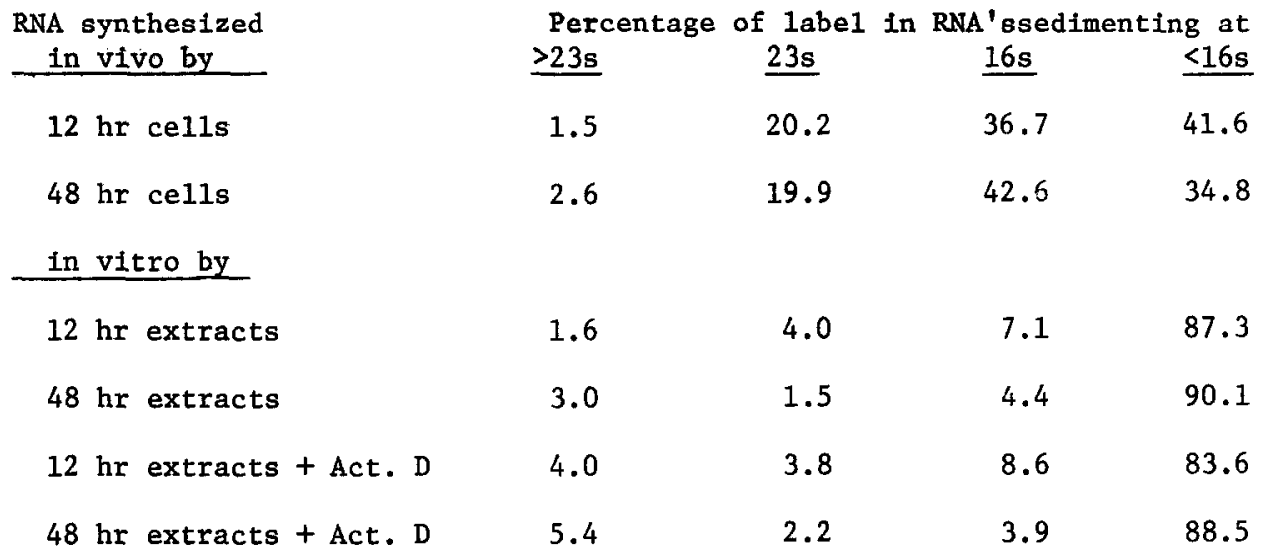

An estimate of the relative proportions of ${ }^{3} \mathrm{H}$-labelled RNA species in the sucrose gradients of Figs. 1 and 2 was obtained by suming the counts per minute representing RNA's sedimenting: (1)more rapidly than 23s; (2)at 23s; (3) at 16s; (4)more slowly than 16s. Each sum was then expressed as the percentage of the total radioactivity recovered from the gradient in question. The data presented represent the average of two experiments.

portion of the labelled RNA sedimenting at greater than $23 \mathrm{~s}$ was observed in the $48 \mathrm{hr}$ profile as compared with the $12 \mathrm{hr}$ cell-free products. Finally, Table I shows that the proportions of stable RNA species synthesized under cel1-free conditions in the presence of actinomycin $D$ are similar to those observed in its absence.

Patterns of RNA synthesis in S. antibioticus - Several general conclusions can be drawn from the data presented above. First, the absorbance patterns of Fig. 1 indicate that there is a significant decrease in the relative amounts of rRNA present in $48 \mathrm{hr}$ cells as compared with $12 \mathrm{hr}$ cells. Between 12 and $48 \mathrm{hr}$, the amount of $16+23 \mathrm{~s}$ RNA in the cells decreases by a factor of three. Second, the decrease in the ability of $48 \mathrm{hr}$ cells to incorporate ${ }^{3} \mathrm{H}$-uridine into RNA ascompared with $12 \mathrm{hr}$ cells is manifested as a generally decreased production of all the major stable RNA species in the cells (Table I). These data indicate that no selective inhibition of the synthesis of specific stable RNA species occurs as the cells begin to make actinomycin.

The observed decrease in the ability of $48 \mathrm{hr}$ cells to incorporate 
3 H-uridine as compared with 12 hr cells may be caused by: (1)an increase in the size of the nucleotide precursor pool in $48 \mathrm{hr}$ cells; (2) a decline in the overall rate of RNA synthesis; or (3)an increased rate of RNA degradation. The absorbance profile of the RNA obtained from intact 48 hr cells (Fig. 1) does suggest that extensive degradation of rRNA occurs between 12 and $48 \mathrm{hr}$. This observation could not be explained by an increase in precursor pool size. However, it has not been determined whether changes in the rates of RNA synthesis or degradation (or some combination of the two) are the factors causing the decrease in RNA synthesis in $48 \mathrm{hr}$ cells. The residual rRNA and the residual capacity to synthesize rRNA in $48 \mathrm{hr}$ cells may be necessary to supply sufficient ribosomes to support the low levels of protein synthesis which have been observed in aging S. antibioticus cultures (4).

The data obtained on the cell-free synthesis of RNA by $\underline{s}$. antibioticus extracts reveal that actinomycin does not produce a selective inhibition of the synthesis of particular stable RNA species by cell-free extracts, but generally decreases the level of all the species present in $12 \mathrm{hr}$ extracts. This finding, coupled with the observation that RNA synthesis catalyzed by $48 \mathrm{hr}$ cell-free extracts is rather insensitive to inhibition by actinomycin (see above), would suggest that the presence of the antibiotic is not itself responsible for the decreased ability of 48 hr cells to synthesize RNA. It should be noted that the presumed rRNA synthesized under cell-free conditions may not reflect the initiation of new polynucleotide chains in the cell-free extracts. The enzyme systems used are crude ones, and the observed rRNA synthesized by these extracts may represent the addition of nucleotides to preexisting, nascent rRNA chains.

This research was supported by grant number 5R01-CA-12752-03 from the National Cancer Institute, U. S. Public Health Service.

1. Waksman, S. A., Actinomycin-Nature, Formation and Activities. Wiley (Interscience), New York, 1968.

2. Katz, E. and Weissbach, H. (1963), J. Biol. Chem. 238, 666-675.

3. Jones, G. H. and Weissbach, H. (1970), Arch. Biochem. Biophys. 137, 558-575.

4. Collett, M. S. and Jones, G. H. (1974), J. Ultrastructure Res. 46, 452-465.

5. Gallo, M. and Katz, E. (1972), J. Bacteriol. 109, 659-667.

6. Lowry, 0. H., Rosebrough, N. J., Farr, A. L. and Randall, R. J. (1951), J. Bio1. Chem. 193, 265-275. 